This item was submitted to Loughborough's Research Repository by the author.

Items in Figshare are protected by copyright, with all rights reserved, unless otherwise indicated.

\title{
Constructing alternative paths to city-region policy and governance
}

PLEASE CITE THE PUBLISHED VERSION

https://www.routledge.com/Territorial-Policy-and-Governance-Alternative-Paths/Deas-

Hincks/p/book/9780415661379

\section{PUBLISHER}

Routledge (@ Taylor \& Francis)

VERSION

AM (Accepted Manuscript)

\section{PUBLISHER STATEMENT}

This work is made available according to the conditions of the Creative Commons Attribution-NonCommercialNoDerivatives 4.0 International (CC BY-NC-ND 4.0) licence. Full details of this licence are available at: https://creativecommons.org/licenses/by-nc-nd/4.0/

\section{LICENCE}

CC BY-NC-ND 4.0

\section{REPOSITORY RECORD}

Harrison, John. 2019. "Constructing Alternative Paths to City-region Policy and Governance". figshare. https://hdl.handle.net/2134/19510. 


\title{
CONSTRUCTING ALTERNATIVE PATHS TO CITY- REGION POLICY AND GOVERNANCE
}

\author{
John Harrison \\ Department of Geography \\ Loughborough University \\ Loughborough \\ Leicestershire \\ United Kingdom \\ LE11 3TU \\ $+44(0) 1509228198$ \\ j.harrison4@lboro.ac.uk
}

Draft - June 2015

Hincks, S., and Deas, I., (Eds.) Alternative Paths to Territorial Policy and Governance.

Routledge: London. 


\section{CONSTRUCTING ALTERNATIVE PATHS TO CITY- REGION POLICY AND GOVERNANCE}

“... regional economic growth has to some extent become a symbolic area of policy where governments have to look interested without necessarily solving the problems." (Niklasson, 2007, p.27)

\section{INTRODUCTION: AN ALTERNATIVE TO WHAT?}

Something which is not hard to find in narratives about territorial governance and policymaking is alternatives, with intellectual and practical debates over regional economic development proving to be no exception. Intellectual alternatives have been derived, in the main, from the either/or debate between 'territoriality' and 'relationality' as opposing ontological and epistemological standpoints which characterised regional studies throughout the 1990s and 2000s. As avant-garde relational approaches were championed as superior alternatives to supposedly more antiquated territorial-scalar approaches, the legacy of this territorial/relational divide in regional studies remains evident through a lexicon of spatial grammar distinguishing 'spaces of flows' from 'spaces of places' (Castells, 1996), 'new regional worlds' from 'the regional world' (Harrison, 2013; Jones and Paasi, 2013), 'unusual'/'non-standard' regions from 'usual'/'standard' regions (Deas and Lord, 2006), and 'soft' and 'hard' spaces of planning and governance (Allmendinger and Haughton, this volume). Directly related to this intellectual debate, many of the practical alternatives result from recent endeavours to design networked, flexible and smart forms of subnational planning and governance arrangements, which, within policy debates, are often viewed as better able to reflect the realities of regional spatial configurations. 
The focus of this chapter is on the scale of the city-region, where these intellectual and practical debates have featured prominently in the search for alternative paths to regional territorial development and governance. At the beginning of the twenty-first century, academic and political discourses of regional economic development have in some cases moved from promoting a "global mosaic of regional economies" (Scott, 1998: 47) toward championing a "global mosaic of city-regions" (Scott, 2011: 862) as the spatial foundations for a globalizing world. This shift has seen city-regionalism presented as a more appropriate path to territorial development and governance. While conventionally configured hard regional spaces provided the cornerstone for the original 'new regionalist' proposition centred on regions as competitive and strategic territories in an emergent multilevel hierarchy extending from the global to the local, the growing policy focus on cityregions has coincided with increased scholarly interest in understanding the form and function of emerging networked regional spaces. The latter has involved important questions about the (in)compatibility of city-regions - as well as other networked spatial imaginaries - with extant state spatial structures which are predominantly territorially bounded (Ward and Jonas, 2004; MacLeod and Jones, 2007; Harrison, 2010, 2013; Jonas, 2013; Harrison and Growe, 2014).

Occupying the minds of academics, politicians, and policymakers alike, it is widely accepted that policies aimed at building institutional capacity at the scale of city-regions is an officially institutionalised task for many countries across the globe (see Herrschel, 2014; Salet et al., 2003; Vogel et al., 2010). The United Kingdom (especially England) has been no exception: as the in vogue spatial scale among policy elites, the period 'after regionalism' has seen governments of all political persuasions launch a succession of actual and proposed initiatives designed to operate at a, variously defined, city-regional scale (Harrison, 
2012). There can be no doubt that this conveyor belt of new 'city-region' initiatives has been successful in sustaining interest, debate and discussion. But for all that alternative paths to city-region development, policy and governance abound, the question of 'an alternative to what' has been overlooked. This chapter argues that in some instances this question of 'an alternative to what' is overlooked completely while at best it seems only to be acknowledged to justify warranting a new 'city-region' initiative before quickly fading into the background. This is despite, I would argue, a real sense of déjà vu both intellectually (Harrison, 2007) and practically (Jones, 2013) as similar weaknesses present themselves time and again in ideas and initiatives purporting to offer real alternatives to the failings of previous endeavours in sub-national economic governance.

In this chapter I argue that myopia to the question of 'an alternative to what' has led to a paralysis of city-regionalism, both intellectually and practically. To develop this argument Section 2 examines England in the period 'after regionalism'. Paying particular attention to the Cameron-led government's flagship policy for sub-national economic development, this section explores the question: if Local Enterprise Partnerships (LEPs) are the solution what is the regional economic development and governance problem they are purported to solve? Arguing that a series of longstanding institutional weaknesses have once more been rolled forward in the design of LEPs, Section 3 then presents two options the first a non-state approach, the second a region-first approach - which might conceivably be considered a more authentically 'alternative' path to city-region development, policy and governance. Finally, the concluding section reflects on what these alternative narratives about territorial governance and policymaking at the scale of city-regions can tell us about the challenges and opportunities for city-regionalism to bring about meaningful territorial development through appropriate governance arrangements. 


\section{2. 'AFTER REGIONALISM' AND THE PARALYSIS OF CITY-REGION POLICYMAKING}

City-regions have for many years been presented as an alternative to regional governance in England (Geddes, 1915; Dickinson, 1964) but latent interest in city-regions only resurfaced in the last two decades. In the wake of the 1998 Regional Development Agencies Act, the Blair governments' efforts to develop economic regionalism (via Regional Development Agencies) and political regionalism (through democratically elected Regional Assemblies) proceeded falteringly, leaving a space into which the idea of city-regions was inserted. Indeed, one commentator suggested the existence of a 'missing middle' in English territorial governance and the need for meso-scale sub-national institutions to occupy the void between the central and local government in respect of economic development (Harding, 2000). While such suggestions ran very much counter to the thrust of the then government's emphasis on regionally based governance, interest in city-regions began to grow much more markedly after 2004 and North East England's rejection of proposals for a directly elected regional assembly as potentially the first of a series of such bodies nationally. This heralded the eventual demise of the Labour Government's territorially-embedded project of political regionalism. In the months after the North East referendum political leaders at all levels, in their search for palatable alternative narratives for territorial governance and policymaking in England, began increasingly to alight on city-regions.

\subsection{The rise and fall of city-regionalism in England}

The focus on city-regions is underpinned by a clearly identifiable intellectual and practical rationale. Intellectually city-regionalism is rooted in a geoeconomic logic pertaining to globalization, competition and agglomerative economic development. Owing to the 
propensity for high-value economic activity to cluster in dense metropolitan-scaled agglomerations we can find plenty of assertions to the effect that city-regions constitute important building blocks in an increasingly globalised modern world. In fact, the connection to the global economy is deemed so pronounced that some influential proponents of cityregionalism have argued that city-regions operate quasi-independently of the nation-state, increasingly escaping its regulatory control through their ability to transcend state territorial boundaries (Scott, 2001).

Captivated by the strong economic growth experienced by so-called 'global' cityregions, policy elites became more convinced of the need to coordinate and integrate policy at the scale of city-regions. As part of a wider reorientation away from spatially redistributive models of regional policy, the city-region became the spatial scale of choice among those who favoured more urban-centric, competitiveness-oriented forms of locational policy. In the race to 'get on' and 'get ahead' as cities and regions vied for prestige amongst their international peers, pressure exerted by policy elites centred on the need for the state to create new, or modified, city-regional strategies to bolster their competitive advantage and enhance their attractiveness to transnational capital.

In England, the Core Cities Group (a representative group of the eight most economically important cities outside London) mobilised in the late 1990 s to lobby the UK Government on precisely this premise. Their contention was (and remains) that enhanced powers and increased resources would allow the major regional cities to add additional cylinders to the UK economic engine, in turn rebalancing the UK economy and providing a counterweight to England's one truly 'global' city-region - London. Allied to this are a series of more localised practical concerns relating to the under-bounding of English cities, the fragmented nature of metropolitan areas and difficulties encountered by neighbourhood 
authorities in developing collaborative strategy, and the aforementioned stalling of the incumbent Labour Government's planned programme for the further regionalisation of activity in England (Harrison, 2012).

Responding to both intellectual and practical arguments for city-regionalism, much of the focus in England 'after-regionalism' has concentrated on making necessary adjustments to reorientate territorial governance and policy initiatives toward the scale of city-regions. A series of government initiatives was launched to this effect, including: the Sustainable Communities Plan (2003), The Northern Way city-region growth strategy (2004), City/Economic Development Companies (2006), Multi-Area Agreements (2006), Statutory City-Regions (2009), Local Enterprise Partnerships (2010), Elected City Mayors (2011), City Deals (2011) and Combined Authorities (2011). All have been designed to operate at a citywide or city-region scale, bring forward the promise of new powers, freedoms and flexibilities to metropolitan areas, and with an almost exclusive focus on areas outside of London - which, uniquely in the UK context, already had what in effect was its own cityregional authority from when the Blair Government established the Greater London Authority in 1999 (Travers, 2002).

In England, as elsewhere, city-regionalism was presented as a clear spatial, institutional and discursive alternative to regional and state territoriality. Yet the singular logic which saw city-regions framed in this way was quickly lost in the period afterregionalism. In public policy discourse city-regions remained one among many other competing spatial imaginaries - localisms, city-regionalisms, subregionalisms and panregionalisms - for intervening in sub-national economic development (Pike and Tomaney, 2009). Despite achieving a position of international orthodoxy in academic and policy circles, as well as garnering considerable enthusiasm among policy elites nationally, 
city-regionalism never secured political consensus as the a priori spatial scale for public policy intervention in England.

If the period after-regionalism signalled the dissolution of regionalism as a single political project, it certainly did not mark the demise or absence of regions, regional institutions and regional power. Neither in fact did it signal the demise or absence of regions as a political project. Between 2004 and 2010 the Labour Government kept their regional project on life support with a series of new initiatives including Regional Ministers, Regional Grand and Select Committees, and a Regional Economic Council, but none of these gained any traction. They also made Regional Development Agencies responsible for city-regional initiatives developed as part of the wider Northern Way. Going a long way to explaining why city-regionalism has so far failed to deliver a genuinely alternative path to territorial development, governance and policy, one important consequence of this further regionalisation of subnational activity was that extant regional power saw city-regions spatially reconfigured along less exclusive lines in order that they became more territorially inclusive (Harrison, 2010; 2013). In sum, there was no smooth transition to a post-regional landscape comprising more networked regional spaces while what marked city-regionalism out as an alternative path to territorial development, governance and policy had effectively been eroded in the latter years of the Labour Government. Allied to this, many 'city-region' initiatives were not in fact new but the result of reworking and rebranding extant institutional arrangements through a process of scalar amplification or contraction (Lord, 2009).

The formation of a Conservative-Liberal Democrat coalition government in 2010 saw further efforts to identify alternative paths to territorial governance and policy. The 
incoming Minister made explicit a wish to finally eradicate the vestiges of Labour's regional project and embark on an alternative path of territorial policy and governance:

"I've set about abolishing all the 'R's - Regional Spatial Strategies, regional housing targets, Regional Assemblies, Government Offices for the Regions and Regional Development Agencies. We've said our goodbyes. The arbitrary regional tier of government administration and bureaucracy was unpopular, ineffective and inefficient. So it's the end of regional government: we need a new era of localism." Eric Pickles, Secretary of State for Communities and Local Government (2010: n.p.)

Replacing Labour's regional structures were Local Enterprise Partnerships (LEPs) as the institutional centrepiece of the new agenda for sub-national economic development. Joint local authority-business bodies charged with promoting local economic development, LEPs were to operate across functional economic areas. In this way, localism was presented as an alternative political project to regionalism, LEPs an alternative institutional arrangement to RDAs, and functional economic areas the 'natural' spatial alternative to 'unnatural' regional blocks (HM Government, 2010, p.13). Yet, for the all discursive framing of localism, LEPs and functional economic areas as an alternative path to territorial policy and governance, the reality of implementation failed to match the rhetoric of design. On the crucial issue of spatial economic governance, although the LEPs initiative signalled something of an embrace of city-regionalism in England, and some individual LEPs branded themselves as city-regional, their designated areas were "not credible" and "fall short of the principles" necessary to be deemed genuinely city-regionalism in form (Coombes, 2014, pp. 2430-2431; see also Pike et al., 2012). The result is that LEPs, in effect, operate as de facto regional entities: spatially inclusive, territorially bounded, state sanctioned.

This casts doubt on the claim that localism and the LEPs provide a credible alternative to regionalism in England. But it also places the spotlight back on to the broader 
question of whether city-regionalism, as a political project, can be successfully implemented and provide the alternative path to territorial policy and governance its proponents argue is necessary to deliver meaningful economic prosperity, tackle entrenched inequalities, and enable smart sustainable planning. For if we have learnt anything from the past decade it is that city-regional policy and governance have developed in an uneven way spatially, and progress has been incremental in respect of actual structure and policies. In saying this let me be clear that I do not deny there are examples of successful interventions being made by actors working in or for English city-regions; rather it is that these localised successes have often been achieved in spite, rather than because, of the overall political-economic framework within which city-regionalism, as a political project, has been forced to operate.

\subsection{The limitations of city-region policymaking}

The limitations of city-region policymaking reflects three facets of state power. Firstly, there remains the continued reluctance of the central state to devolve authority alongside responsibility to sub-national institutions. In fact, if the transition from RDAs to LEPs is anything to go by we can go so far as to say that the trend was for spatial economic governance becoming even less governmentalised in England. LEPs lacked much in the way of central funding, particularly in their early years (the combined annual budget for RDAs reached $£ 2.2$ billion whereas LEPs began with a $£ 5$ million Start-up Fund and $£ 4$ million Capacity Fund, with a further $f 1.4$ billion available on a competitive basis over a three-year period through the Regional Growth Fund), had no statutory planning role (RDAs were statutory planning bodies in their final years), and although nominally private-sector led they were heavily reliant on local authorities for staffing and assistance. Here lies the great paradox of spatial economic governance in England: contemporary sub-national institutions 
have been given responsibility for rebalancing an increasingly polarised space economy, yet have been granted fewer powers and resources than their predecessors.

Secondly, political discourses sometimes assume a more or less blank conceptual or policy base, but the reality is there is no tabula rasa when it comes to establishing new institutional frameworks for spatial economic governance. To understand this we need to distinguish between the geoeconomic and geopolitical logics that underpin city-regionalism (Jonas, 2013). Returning to the earlier example, the framing of LEPs provides a classic example of how capital-centric discourses of globalised economic competitiveness are used to justify further erosion of what are presented as archaic state-centric approaches:

"The secret to success is natural local economies - not artificial political regions that better reflect the natural economic geography of the areas they serve. This is an economic problem that needs an economic solution, not a political one." (Pickles and Cable, 2010, n.p.; emphasis added)

Yet, if the establishment of LEPs reminds us of anything it is that for all this posturing cityregionalism, with all of its relational inflections, is as much about state territorial power as it is discourses of globalised economic competitiveness. The spatial configuration of 39 LEPs reveals that over half serve areas based on the historic geographical counties of England, while only three areas have a core geography which is transregional. In part, the conservatism of the LEP geography reflects some of the practical difficulties in securing agreement among local authority and business leaders over the course of a period which extended to only 69 days in 2010. But the LEP geography also reflected a more fundamental shift in thinking. The globalisation inspired economic logic for adopting more competitive, selective and differential approaches to spatial economic governance was increasingly 
bypassed to assuage political demands that LEPs be seen to provide an inclusive approach to regional development.

The answer can be found in a third point, which is the actions of the state cannot be detached from the ballot boxes through which elected officials are ultimately held accountable and which remain territorially defined. State-led city-regionalism is preconditioned to use the geoeconomic logic for city-regions as agglomeration economies to justify initiatives which privilege urban spaces over non-urban spaces. However, to maintain their own legitimacy and maintain regulatory control and management of the economy in the context of a globalising economy, state actors have expanded the ambit of city-regional governance and policy, augmenting geoeconomic logic for more exclusive regional development with a geopolitical logic that emphasises the need to retain inclusive approaches to regional development. One important consequence of politically (re)constructing city-regions in this way is that over the past decade state-led cityregionalism has been caught betwixt and between two opposing rationales, constantly facing up to the challenge of trying to reconcile geoeconomic demands for more exclusive city-regional development with geopolitical concerns for more emphasis on inclusive cityregional development.

On the general issue of city-regionalism as an alternative path to territorial policy and governance these developments point to it "becoming increasingly difficult to disentangle the new economic geography of city-regionalism from its geopolitical construction" (Jonas, 2012, pp. 822-823). Nonetheless, this paralysis of state-led city-region policymaking has not gone unnoticed. In fact it led to damning early assessments of the LEP project: 
"LEPs are likely to fail. Their modus operandi involves rolling forward existing centrally-orchestrated policy regimes, deploying limited levers and mechanisms to influence the business community, and ultimately being unable to correct deeprooted market failures." (Jones and Jessop, 2010, p. 1144)

Moreover, the All Party Parliamentary Group (APPG) on Local Growth, Local Enterprise Partnerships and Enterprise Zones (2013: 7) pointed out that, despite endeavours by the state to furnish LEPs with new powers, competences and resources, this was offset by the Government's "inconsistent approach to localism; unresolved issues about whether the LEPs are competitors or collaborators; the risk of function creep and bureaucratisation; LEPs' limited resources and the need for a collective LEP voice". A national survey of LEPs led by the Centre for Urban and Regional Development Studies (CURDS) went even further, arguing that:

"given the lack of long-term vision and strategy for their strategic development, the fundamental tensions yet to be resolved and their institutional deficits in authority, capability and resources, at this stage in their evolution the LEPs will struggle to exercise substantive influence upon local economic growth. Continued state austerity, chronic low growth and brittle and uncertain economic conditions in the short and medium-term will further trouble this central task." (Pike et al., 2013: 36)

Despite such downbeat assessments the concern is that there appears to be no alternative to LEPs being considered. The point here is that in these and other critiques (notably Heseltine, 2012), the assumption is that LEPs - and state-led approaches more generally are the answer. But if LEPs are the solution what is the territorial development, governance and/or policy problem they are purporting to solve? We need to ask this question because uncertainty regarding the future direction of city-region governance and policymaking is exacerbated by the contradictions inherent in state-centric approaches and by the restrictions the state imposes on city-regionalism as a political project. For this reason, the 
remainder of this chapter looks beyond state-centric models to examine two alternative paths for future city-regional governance. The first considers the increased privatisation of urban and regional development, examining how newly emergent capital-centric models of city-region policy and governance are impacting upon the balance between capital and state interests. The second examines the potential that functionally dominant approaches to constructing city-regions afford in overcoming the tensions between city-first and regionfirst approaches to sub-national territorial governance.

\section{CONSTRUCTING ALTERNATIVE PATHS TO CITY-REGION POLICY AND GOVERNANCE}

\subsection{Constructing a non-state alternative to city-region policy and governance}

Over the past decade a critical body of work has emerged documenting how state-led privatisation of urban and regional development has increased the potential for capital interests to engage more prominently in territorial policy and governance (Raco, 2013). Nevertheless, Syrett and Bertotti (2012) have recently argued that failures to understand the motives behind why businesses choose (not) to engage, the tactics and strategies businesses employ when they do engage, and the impact their involvement has on practice mean that state-centred models for territorial policy and governance "provide a fundamentally flawed governance model for addressing the practical realities of pursuing sub-national economic development" (Syrett and Bertotti, 2012, p. 2312). Early evaluations of the LEP programme only served to reinforce this view, with business involvement generally seen to be "thin" (SQW, 2010, p. 6) and where they were engaged business leaders were already "ready to walk away" if the parameters of this state-centred model meant they were unable to effect change (Cominetti et al., 2012). 
With business leaders frustrated by the constraints of state-centred models being repeated in new institutional forms, a more recent trend in narratives of territorial development, policy and governance is the rise of non-state spatial strategies operating at a city-wide or city-region scale. International examples range from Siemens (engineering), BASF (chemicals) and Volkswagen (automotive) moving beyond their corporate interests to become actively engaged in metropolitan-scaled policymaking activities as they seek influence over spatial development practices in Erlangen, Rhine-Neckar and Wolfsburg respectively (Knieling et al., 2012), to the corporate mining sector governing public land use decisions in Queensland, Australia (Morrison et al. 2012). A UK example worthy of further investigation is the case of a private investment company ('The Peel Group': hereafter Peel) who in 2008 launched a private-sector strategy for unlocking economic development potential in the 'Atlantic Gateway', an area linking the city-regions of Liverpool and Manchester (Deas et al., 2015). One of the most striking features of these more capitalcentric approaches is the enhanced possibilities for business involvement, engagement and leadership in territorial policy and governance at the metropolitan scale. More open questions relate to why (now) these companies are choosing to engage in this way, how they are seeking to shape patterns of urban and regional development, and how they can impact on the future evolution of city-region policymaking (Harrison, 2014a/b).

Turning to examine the first of these questions, Peel is a private investment group with assets worth over $f 6.5$ billion, most of which are concentrated along a $50 \mathrm{~km}$ urban corridor connecting the Liverpool and Manchester city-regions. From an initial focus on land and property investments in the 1970s and 1980s, Peel has been expanding to a position where it now has a diverse portfolio of activity (e.g. Peel Airports, Peel Energy, Peel Leisure, Peel Media, Peel Ports) and major equity stakes in national and international companies (e.g. 
Intu Properties, UK Coal, Pinewood film studios, Vantage Airports Group). Looking to capitalise on extensive land and property assets in North West England, Peel launched Atlantic Gateway, an ambitious proposal to invest $£ 50$ billion in 50 projects up to 2050 . Through Atlantic Gateway Peel signalled its intention to move beyond selective engagement with state actors (notably the former North West Regional Development Agency (NWDA)) and begin increasingly to fulfil a role as strategic leaders in shaping patterns and trajectories of urban and regional development. This shift was rooted partly in Peel's corporate aspirations. Atlantic Gateway revealed Peel's long-term desire to move beyond delivering individual large-scale developments (e.g. the $f 650$ million MediaCityUK) to develop much larger scale, longer-term and multi-sector schemes to regenerate whole areas (e.g. the $>£ 5$ billion proposals currently for Liverpool Waters and Wirral Waters). Peel's ambitious investment plans are fuelled by the potential corporate benefits they deliver. Nevertheless the complex nature of these multi-billion pound investment schemes puts them under increased public scrutiny, not least in the planning approval process where delays and/or rejections to any part of the scheme will incur additional costs and reduce potential returns on investment. Indeed, Peel had previous experience of the financial consequences of protracted planning decisions having been involved in a nine year dispute (1986-1995) over its plan to build the Trafford Centre, a major out-of-town retail centre opposed by most of Greater Manchester's local authorities.

Seizing upon opportunities presented by the ongoing privatisation of urban governance, the prolonged post-financial crisis economic downturn, and changes in the national political discourse, Peel took the opportunity to construct a case for a special purpose planning vehicle to - in the words of Peel Chairman, John Whitaker - "overcome individual local authority objections" in the delivery of Atlantic Gateway (quoted in Barry, 
2008). Peel's strategy involved capitalising on its urban economic infrastructure assets to broker a deal with the NWDA for them to assign Atlantic Gateway priority status in the 2010 Integrated Regional Strategy (RS2010). Appearing in RS2010 was critical to Peel's strategy. As a statutory planning document, RS2010 would see the NWDA act as planning authority for Atlantic Gateway and reinforce Peel's case in planning disputes. Although RS2010 identified the Atlantic Gateway as the North West's key spatial priority (NWDA, 2010), the Cameron-led coalition government subsequently revoked statutory regional planning provisions. Peel moved swiftly, proposing Atlantic Gateway as a "private-sector led special purpose LEP" (Peel, 2010: ii). Subsequently withdrawn as a LEP proposal in the face of opposition from some local authorities, Peel nevertheless ensured a special delivery vehicle was agreed, strategically aligned and integral to the three LEPs established across the Atlantic Gateway.

Peel's political manoeuvring is significant because unlike state-centric models, when private sector involvement is often preceded by state actor efforts to script a role for business, the Atlantic Gateway shows the example of business leaders using city-regionalism as a mechanism to negotiate better terms of cooperation. Having lost their main regional ally in the form of the NWDA, Peel's new approach is using Atlantic Gateway to exert their influence not just regionally but nationally. The Conservative-led government on its election in 2010 championed private-sector led economic recovery, spatial and sector rebalancing of the economy, better dialogue between capital and state interests in shaping political praxis, and post-recession growth and competitiveness through infrastructure-led economic regeneration. Peel could therefore lobby central government to provide appropriate resources in support of Atlantic Gateway initiatives which fitted with this wider approach to economic development. This is significant because capital-centric city-regionalism clearly 
offers something different to the forms of sub-national governance and policymaking that have tended to predominate in Britain to date. The argument that "we need LEPs with larger areas, proper funding for running costs, experienced staff, and access to capital" (Ward and Hardy, 2013, p. 9) has prompted some to argue that Atlantic Gateway represents a model for LEPs and other institutions of spatial economic governance:

"If anywhere in the UK can develop the critical mass and momentum to become an alternative growth pole to London, it is the Atlantic Gateway ... [for] there has never been a credible proposition of that nature in Britain to achieve something decades of [state-centred] regional policy failed to achieve." (Heseltine and Leahy, 2011, p. 5657)

In contrast to LEPs (and RDAs before them), Atlantic Gateway is genuinely business-led. Heseltine and Leahy (2011) among others have argued that non-state spatial strategies may provide a genuine alternative to existing forms of city-region policy and governance. But with the emergence of new non-state spatial strategies comes some not insignificant concerns. Favouring capital over state interests in city-region policy and governance brings new opportunities, but also risks and threats. While private sector assets, power and expertise give businesses a significant voice in influencing and shaping patterns of urban and regional development, their lack of democratic legitimacy undermines their ability to govern city-regions in a more expansive way. It can be argued in this respect that companies such as Peel recognise their lack of a democratic mandate, but nevertheless perceive an acute need for private sector resources in order to make viable economic development strategies: "fundamentally, the era of predominantly public finance investment in infrastructure is over and thus regeneration programmes will have to adapt o this new environment" (Howell, 2012, p. 5). In the case of Atlantic Gateway, recent announcements suggest the state's 
tactic is one that involves capturing, co-opting and reworking Peel's non-state vision for cityregion development into a state spatial strategy for Northern England (One North, 2014; Osborne, 2014).

\subsection{Constructing a region-first alternative to city-region policy and governance}

One of the difficulties confronting city-region policymaking is the politically thorny issue of spatial selectivity and the extent which some sub-areas are prioritised at the expense of wider socio-spatial inclusivity. This is an issue that looms large in academic and political debate:

"The city-region approach reproduces a rural development problem. It establishes and reinforces out-of-date notions of geographical centrality and hierarchies, and it actively marginalises places, consigning them to the periphery, dividing and polarising." (Ward, 2006, p. 52 emphasis added)

"City-regions are an innovative way to manage urban-rural interaction, but at present the rural component seems to be ignored." (OECD, 2011, p. 222)

In the first quote we see an argument pertaining to current city-region approaches (see section 2 above), implicitly bemoaning the lack of any clear alternative path to city-region policy and governance which would allow for greater inclusion and intra-regional sociospatial equity. The second quote from the OECD points toward the related issue of how far city-regionalism privileges major agglomerative economies at the expense of the marginalisation or non-urban spaces. But are there city-regional narratives? This section considers an emerging body of literature which frames city-regionalism through a regionsfirst as opposed to cities-first approach to defining and conceptualising city-regions (cf. Harrison and Heley, 2015). 
Working from a belief that city-regionalism's "implicit marginalisation of rural areas is unwelcome", Coombes (2013, pp. 2429-2430) argues that a crucial point when defining city-region boundaries for governance or policy is to recognise that "there is an alternative conception of city-regions which does not presume such a dominant role for the city". Pushing beyond Soja's (2013) notion of regionalised urbanisation and Herrschel's (2014) distinction between urban-centric city-regions and regionalised city-regions, Coombes challenges the consensus of a city-first approach to city-regionalism by testing the idea that regions could (or even should) have primacy over cities when defining the boundaries of city-regions for governance or policy. To understand the potential significance of this we need, first, to reflect on some of the difficulties that currently confound city-region policymaking. Over the past decade or more, endeavours to define boundaries for cityregion governance or policy have swayed between a spatially-selective, city-first, agglomeration approach infused by more capital-centric discourses of globalised economic competitiveness, and the more territorially-inclusive, region-first approaches promoted by the state.

In his analysis, Coombes examines migration and commuting flows in England to argue that a regions-first approach to defining city-region boundaries for governance or policy is capable of "implementing all the fundamental features of the concept" $(2014, p$. 2426 emphasis added). The resultant map is a mosaic of 39 areas which is, in effect, only a slight variation on the current structure of 39 LEPs. Despite a different starting point (the region rather than the city) the outcome is a newly proposed de facto scale for sub-national governance. Moreover, as Coombes (2014, p. 2440) points out, his empirical analysis "finds no 'non-city-region' in England". Amounting to an important first step in establishing the principle of defining city-region boundaries for governance or policy by adopting a region- 
first approach, the result is arguably not too dissimilar to previous attempting to delimit functional regions.

One territory of the UK does nevertheless appear to present an approach to constructing city-regions according to functional regionalism without necessarily falling back into the city-region trap caused by the agglomeration and scale models. In 2004, the first Wales Spatial Plan (WSP) had all the hallmarks of the spatially-selective, city-centric, agglomeration model of city-regionalism. The spatial vision presented six loosely-bounded regional areas, each an urban agglomeration shown to include 33 of the 35 'key centres' and expanding their reach outwards into non-urban areas (Welsh Assembly Government (WAG), 2004, Figure 2, p. 7). Making the Welsh case pertinent is that by the time the second WSP was published in 2008, policy elites had unmistakeably developed a new approach to cityregionalism consistent with the underlying principles of relational regionalism (WAG, 2008).

Very much in line with recent intellectual arguments pertaining to the pervasiveness of urban-economic processes across all geographic space (e.g. Scott, 2011, 2012; Brenner, 2013), the urban-rural divide so evident in WSP 2004 has been diluted in WSP 2008 by adopting a functionally-dominant regions-first, rather than a form-dominant cities-first, approach to city-regionalism. The result is an opening up of city-regionalism to include 57 'key settlements'.

Including those settlements on the fringes (or even beyond) urban areas is significant for three principal reasons. First, WSP 2008 recognises that:

"[Rural] market towns differ from the extensive urban areas ... in their relative isolation, their enhanced service function compared to population and their interactions with the surrounding rural areas. Because of the Area's rurality, relative peripherality and population sparsity, its most populous settlements need to fulfil roles and functions that would normally be associated with much larger towns." (WAG, 2008, p. 85). 
WSP 2008 is important because it recognises non-city-regions. Functional nodes located in non-urban areas - that is, those that do not easily conform to a city-regional profile and are therefore automatically excluded from form-dominant cities-first approaches - are now included in the discursive framing of Welsh city-regionalism. It recognises that although market towns and tourist hotspots do not easily conform to the stereotypical profile of 'cityregion' in their physical appearance, their multifunctional role within the non-urban areas in which they are located needs to be recognised.

Secondly, WSP 2008 enabled the Welsh Assembly Government simultaneously to recognise and prioritise growth in and beyond metropolitan regions. One important consequence of recognising functional regionalism beyond metropolitan regions is that the framing of WSP 2008 achieves a much greater degree of spatial inclusivity than the citiesfirst agglomeration approach, and without the explicit territorial division that results from the scalar approach of partitioning and fragmenting space. In short, the typology of key settlements softened the perception that city-regionalism was prioritising growth in a smaller number of more significant urban regions, while also producing the fuzzy boundaries now commonly associated with the emergence of 'soft' (or perhaps more accurately 'softer') spaces for regional planning and governance (Heley, 2013).

\section{IS CITY-REGIONALISM DRINKING IN THE LAST CHANCE SALOON?}

We do not need alternatives for alternatives sake in intellectual and practical debates over regional economic development. What we do need are solutions to established problems. This requires ideas that are not only alternative in their style but more importantly in their substance and implementation. This chapter has sought to unpack the notion of alternative 
paths to city-region development, policy and governance. Focusing on city-regions is important. Debates surrounding city-regionalism inform broader intellectual discussion in urban and regional studies, particularly in relation to understanding when and where territoriality and relationality appear compatible. Even where the two appear incompatible, it is important to examine how actors have attempted to reconfigure territories in order that they become more complementary (Harrison, 2013; Harrison and Growe, 2014; Paasi and Zimmerbauer, 2015). On a more practical note, city-regions continue to be championed as the "ideal scale for policy intervention a globalized world" (Rodriguez-Pose, 2008, p. 1029) but in many cases the path to city-region development, policy and governance has amounted to "reactionary and incremental adjustments that lack strategic direction, buy-in and focus" (Ayres and Stafford, 2009, p. 619).

Reflecting these tensions, the development of city-region policymaking and governance has been geographically uneven, contingent upon a number of factors: (i) cityregional arrangements being less governmentalised than their regional predecessors but tasked with solving a bigger problem (although this now has the potential to change in the UK following the announcement in November 2014 that the Greater Manchester Combined (City-Region) Authority will, under the auspices of an elected 'metro' mayor, have control over $€ 7$ billion of public spending); (ii) there being no blank state, such that city-region policies and initiatives championed as new are generally a reworking of previous institutional structures, territorialities, frameworks and support; and (iii) tension between capital and state interests, manifest in the incompatibility of spatially-selective 'agglomeration' and spatially-inclusive 'scalar' approaches to city-region development, policy and governance. The main argument of this chapter has therefore been that the majority of new - and supposedly alternative - 'city-region' initiatives launched by the UK 
Government over the past decade do not seek to solve the fundamental problems of socioeconomic development, thus constraining the pace and extent of city-region policymaking. Instead they seek to work within parameters established by the state, resulting in a restricted form of top-down territorial governance that, in some cases, is poorly attuned to local circumstances.

Nevertheless, there are plausible alternatives to the restricted forms of city-region governance and policymaking that are evident in some (but not all) British cities. But while examples such as Peel's Atlantic Gateway Strategy or the Wales Spatial Plan represent differing forms of territorial governance, neither ought to be considered exemplary. Both are more symbolic than substantive. Equally, they do stand out from other city-region initiatives because they seek (directly in the case of Peel, indirectly in the case of the Welsh Assembly Government) to provide solutions to the established problems that constrain how city-regionalism is implemented politically. However, and to paraphrase a well-rehearsed refrain in urban and regional studies, what these alternative approaches to city-region policy and governance bring us back to are two fundamental questions which must ultimately be front and centre of our work going forward: namely (i) what kind of city-region development, policy and governance do we want - and possibly need - to shape future patterns of urban and regional development, and (ii) in whose interests should cityregionalism be pursued. 


\section{ACKNOWLEDGEMENTS}

Section 3.1 draws on research funded through a Regional Studies Association Early Career

Grant and Section 3.2 derives from ongoing collaboration with Jesse Heley. Thanks are also due to the editors for their comments on an earlier version of the chapter. 


\section{REFERENCES}

All Party Parliamentary Group on Local Growth, Local Enterprise Partnerships and Enterprise Zones (2013) Rising to the Challenge: How LEPs can Deliver Local Growth Strategies. Westminster City Council: London.

Allmendinger P and Haughton G (2015) 'Alternative planning spaces', in Deas I and Hincks S (Eds.) Alternative Paths to Territorial Development and Governance. Routledge: London pp. 000-000.

Barry C (2008) 'Planning supremo seeks planning revolution'. Manchester Evening News Business Section, 8 September [Last accessed at http://www.manchestereveningnews.co.uk/business/business-news/peel-supremoseeks-planning-revolution-966379 on 22 September 2014]

Brenner N (2013) Implosions/Explosions: Towards a Theory of Planetary Urbanization. Jovis Verlag: Berlin.

Castells M (1996) The Rise of the Network Society. Blackwell: Oxford.

Cominetti N, Crowley L and Lee N (2012) The Business of Cities - The Private Sector, Local Enterprise Partnerships and Growth. The Work Foundation: London.

Coombes M (2014) 'From city-region concept to boundaries for governance: the English case', Urban Studies, 51 (11), 2426-2443.

Deas I and Lord A (2006) 'From a new regionalism to an unusual regionalism? The emergence of non-standard regional spaces and lessons for the territorial reorganisation of the state', Urban Studies, 43 (10), 1847-1877.

Deas I, Haughton G and Hincks S (2015) “"A good geography is whatever it needs to be": the Atlantic Gateway and evolving spatial imaginaries in North West England', in 
Allmendinger P, Haughton G, Knieling J and Othengrafen F (eds.) Soft Spaces: Renegotiating Governance, Boundaries and Borders, London: Routledge, pp. 25-44.

Dickinson RE (1964) The City Region in Western Europe. Routledge \& Kegan Paul: London.

Geddes P (1915) Cities in Evolution: An Introduction to the Town Planning Movement and to the Study of Cities. Williams \& Norgate: London.

Harding A (2000) Is There a 'Missing Middle' in English Governance? New Local Government Network: London.

Harrison J (2007) 'From competitive regions to competitive city-regions: a new orthodoxy, but some old mistakes', Journal of Economic Geography, 7 (3), 311-332.

Harrison J (2010) 'Networks of connectivity, territorial fragmentation, uneven development: the new politics of city-regionalism', Political Geography, 29 (1), 17-27.

Harrison J (2012) 'Life after regions? The evolution of city-regionalism in England', Regional Studies, 46 (9), 1243-1259.

Harrison J (2013) 'Configuring the new "regional world": on being caught between territory and networks', Regional Studies, 47 (1), 55-74.

Harrison J (2014a) 'Rethinking city-regionalism as the production of new non-state spatial strategies: the case of Peel Holdings Atlantic Gateway Strategy', Urban Studies, $\mathbf{5 1}$ (11), 2315-2335.

Harrison J (2014b) 'The rise of the non-state "place-based" economic development strategy", Local Economy, 29 (4-5), 453-468.

Harrison J and Growe A (2014) 'When regions collide: in what sense a new "regional problem"?', Environment and Planning A, 46 (10), 2332-2352.

Harrison J and Heley J (2015) 'Governing beyond the metropolis: placing the rural in cityregion development', Urban Studies, 52 (6), 1113-1133. 
Heley J (2013) 'Soft spaces, fuzzy boundaries and spatial governance in post-devolution Wales', International Journal of Urban and Regional Research, 37 (4), 1325-1348.

Herrschel T (2014) Cities, State and Globalization - City-Regional Governance in Europe and North America. Routledge: London.

Heseltine M (2012) No Stone Unturned in Pursuit of Growth. BIS: London.

Heseltine M and Leahy T (2011) Rebalancing Britain: Policy or Slogan? Liverpool City Region - Building on Its Strengths: An Independent Report. BIS: London.

HM Government (2010) Local Growth: Realising Every Place's Potential. The Stationery Office: London.

House of Commons Business, Innovation and Skills Committee (2013) Lord Heseltine's Report: No Stone Unturned in Pursuit of Growth - Oral Evidence, HC 823-I and -ii. The Stationary Office: London.

Howell S (2012) Grow Your Own Way: Taking a Localist Approach to Regeneration. Local Government Association/Localis: London.

Jonas AEG (2012) 'City-regionalism: questions of distribution and politics', Progress in Human Geography, 36 (6), 822-829.

Jonas AEG (2013) 'City-regionalism as a contingent "geopolitics of capitalism"', Geopolitics, 18 (2), 284-298.

Jones M (2013) 'It's like deja vu, all over again', in M Ward and S Hardy (eds.) Where Next for Local Enterprise Partnerships? The Smith Institute/Regional Studies Association: London, pp. 86-95.

Jones M and Jessop B (2010) 'Thinking state/space incompossibly', Antipode, 42 (5), 11191149. 
Jones M and Paasi A (2013) 'Guest editorial: Regional world(s): advancing the geography of regions', Regional Studies, 47 (1), 1-5.

MacLeod G and Jones M (2007) 'Territorial, scalar, networked, connected: in what sense a 'regional world'?' Regional Studies, 41 (9), 1177-1191.

Niklasson L (2007) Joining up for Regional Development. Statskontoret: Stockholm.

NWDA (2010) RS2010: Future North West - Our Shared Priorities. NWDA: Warrington.

OECD (2011) OECD Rural Policy Reviews: England, United Kingdom. OECD Publishing: Paris.

One North (2014) One North: A Proposition for an Interconnected North. Manchester City Council: Manchester.

Osborne G (2014) 'We need a Northern powerhouse', 23 June [Last accessed at https://www.gov.uk/government/speeches/chancellor-we-need-a-northernpowerhouse on 22 September 2014]

Pickles E (2010) 'It's the local economy, stupid'. Conservative Home [last accessed at http://conservativehome.blogs.com/localgovernment/2010/07/eric-pickles-mp-itsthe-local-economy-stupid.html on 22 September 2014]

Peel (2010) A Response by the Private Sector to the Government's Request for Outline Proposals in Relation to Local Enterprise Partnerships (LEPS) in Respect of Atlantic Gateway. The Peel Group: Manchester.

Pickles E, Cable V (2010) Economy needs local remedies not regional prescription. 6 September, available at https://www.gov.uk/government/speeches/economyneeds-local-remedies-not-regional-prescription [last accessed 22 September 2014]

Pike A and Tomaney J (2009) 'The state and uneven development: the governance of economic development in England in the post-devolution UK', Cambridge Journal of Regions, Economy and Society, 2 (1), 13-34. 
Pike A, Tomaney J, Coombes M and McCarthy A (2012) 'Governing uneven development: the politics of local and regional development in England', in N Bellini, M Danson and H Halkier (eds.) Regional Development Aencies: The Next Generation? Networking, Knowledge and Regional Policies. Routledge: London, pp. 102-121.

Pike A, Marlow D, McCarthy A, O'Brien P and Tomaney J (2013) Local Institutions and Local Economic Growth: The State of the Local Enterprise Partnerships (LEPS) in EnglandA National Survey. Centre for Urban and Regional Development Studies: Newcastle.

Raco M (2013) State-led Privatisation and the Demise of the Democratic State - Welfare Reform and Localism in an Era of Regulatory Capitalism. Ashgate: Aldershot.

Salet WG, Thornley A and Kreukels A (eds.) (2003) Metropolitan Governance and Spatial Planning: Comparative Case Studies of European City-Regions. Spon: London.

Scott AJ (1998) Regions and the World Economy: The Coming Shape of Global Production, Competition, and Political Order. Oxford University Press: Oxford.

Scott AJ (ed.) (2001) Global City-Regions: Trends, Theory, Policy. Oxford University Press: Oxford.

Scott AJ (2011) 'A world in emergence: notes towards a resynthesis of urban-economic geography for the $21^{\text {st }}$ century', Urban Geography, 32 (6), 845-870.

Scott AJ (2012) A World in Emergence: Cities and Regions in the 21st Century. Edward Elgar: Cheltenham.

Soja E (2013) 'Regional urbanization and third wave cities', City, 17 (5), 688-694.

Syrett S and Bertotti M (2012) 'Reconsidering private sector engagement in subnational economic development', Environment and Planning A, 44 (10), 2310-2326.

Travers T (2002) 'Decentralization London-style: the GLA and London governance', Regional Studies, 36 (7), 779-788. 
Vogel R, Savitch H, Xu J, Yeh AGO, Wu W, Sancton A, Kantor P, Newman P, Tsukamoto T, Cheung P, Shen J, Wu F and Zhang F (2010) 'Governing global city regions in China and the West', Progress in Planning, 73 (1), 1-75.

Ward N (2006) 'Rural development and the economies of rural areas', in J Midgeley (ed) $A$ New Rural Agenda. IPPR: London, pp. 46-67.

Ward M and Hardy S (eds) (2012) Where next for Local Enterprise Partnerships? The Smith Institutes and Regional Studies Association: London.

Ward K and Jonas AEG (2004) 'Competitive city-regionalism as a politics of space: a critical reinterpretation of the new regionalism', Environment and Planning A, 36 (12), 21192139. 
Figure 1: 2008 Wales Spatial Plan - The National Vision (WAG, 2008, p. 20)

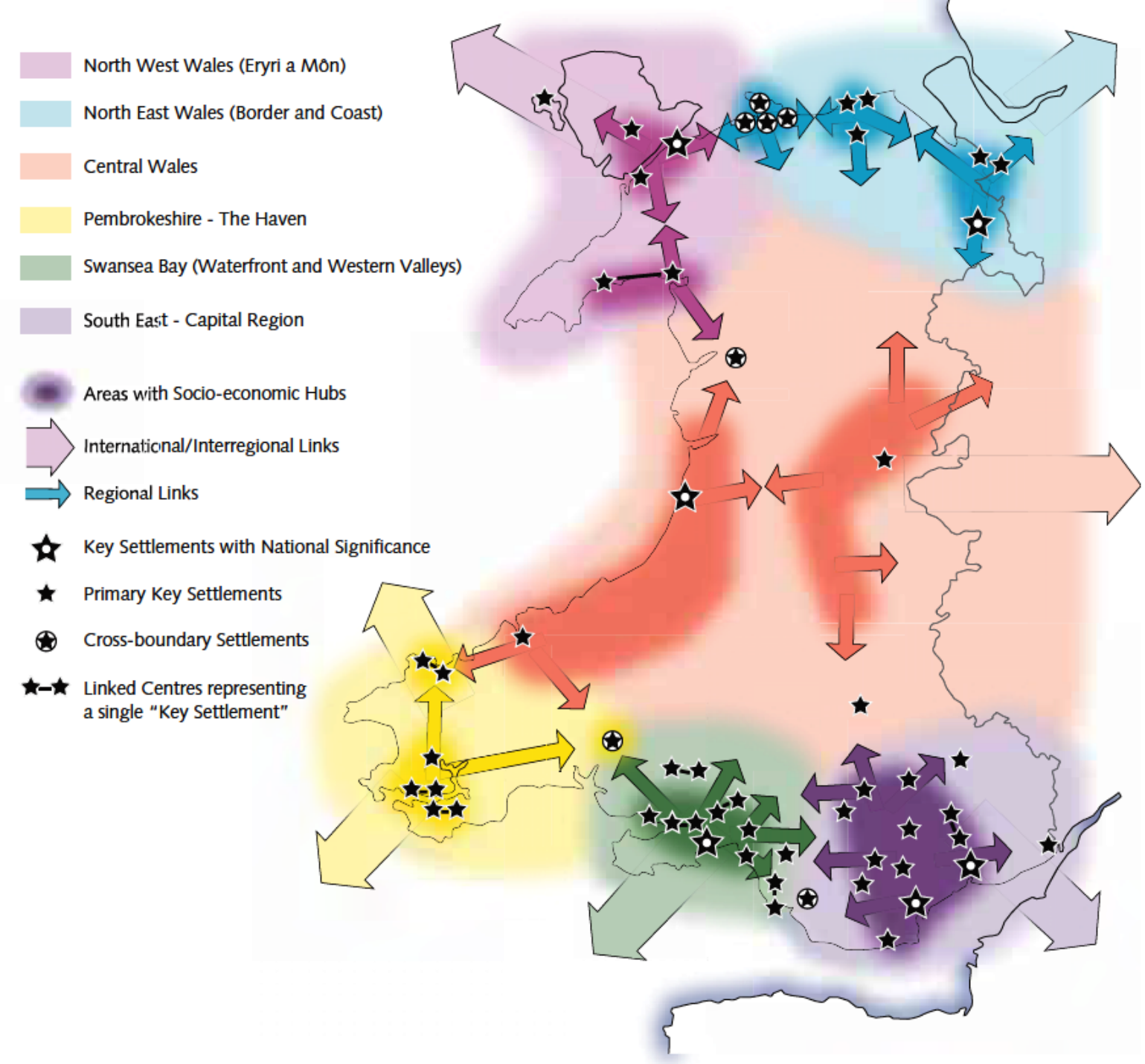

